Article

\title{
Examining the Impact of Workplace Spirituality and Procedural Justice on Work Locus of Control, Employee Job Satisfaction and Employee Organisational Commitment
}

\author{
Eugine Tafadzwa Maziriri ${ }^{1}$, Miston Mapuranga ${ }^{2}$ and Nkosivile Welcome Madinga ${ }^{2, *}$ \\ 1 University of the Witwatersrand, School of Economic and Business Sciences, 1 Jan Smuts Ave, \\ Johannesburg, 2000; eugine.maziriri@wits.ac.za \\ 2 The Da Vinci Institute for Technology, School of Management Leadership, Modderfontein, 1645. \\ mmapuranga@gmail.com \\ 3 University of Cape Town, School of Management Studies, Upper Campus, Rondebosch, 7701. \\ nkosivile.madinga@uct.ac.za \\ * Correspondence: eugine.maziriri@wits.ac.za; Tel.: +27 810405090
}

\begin{abstract}
The present examination explored on the impact of work place spirituality and procedural justice on work locus of control, employee job satisfaction and employee organisational commitment among workers from private institutions of high learning in South Africa. Due to limited researches that have concentrated on the impact of workplace spirituality and procedural justice on work locus of control, employee job satisfaction and employee organisational commitment in developing countries especially in Southern Africa. A review was done and information was accumulated by methods for surveys on a sample of 150 academics and support staff in a private university setting in Gauteng, South Africa. Structural equation modelling was employed to analyse data using the Smart Partial Least Squares (PLS) software. By means of a partial least squares structural equation modelling approach, this study validates that elements such as workplace spirituality, procedural justice and work locus of control are instrumental in stimulating the employee job satisfaction and employee job commitment. The present investigation offers suggestions for academicians in the field of resource management by upgrading their comprehension of the how workplace spirituality and procedural justice impacts work locus of control, employee job satisfaction and employee organisational commitment.
\end{abstract}

Keywords: work place spirituality; procedural justice; work locus of control, employee job satisfaction; employee organisational commitment

\section{Introduction}

Research today on organisational behaviour has highlighted critical antecedents that are supportive or detrimental to the performance of employees (Dajani, 2015:11; Cherian, \& Jacob, 2013; Malik, Nawab, Naeem \& Danish, 2010). Deducing from the preceding proclamation, "this view holds true while focusing on quality of human resources which is a major factor that contribute considerably to the organizational success" (Pohlman \& Gardiner, 2000:1). It is imperative to study behaviour of employees in higher tertiary education providers, in particular, universities which are mainly sources of human capital and solely has a duty of developing intellectual capital of the states.

Malik, Nawab, Naeem, and Danish (2010:17) argue that "both academic and non-academic employees are central element in educational system holding various important responsibilities". "The overall 
performance of universities depends upon their employees and ultimately their level of job satisfaction and organisational commitment. Thus appreciating their behaviours and attitudes needs more attention in organizations" (Mullins, 2007:24). This research aims at examining the hypothesised relationships among the research variables or constructs of the private sector universities such as workplace spirituality and organisational procedural justice's influence on work locus of control, job satisfaction commitment to the organisation.

"Workforces generally feel a sense of calling and responsibility to their work" (Heisserer, \& Parette, 2002). In contemporary, "knowledge capital must be retained in order for the organization to remain productive and responsive to the needs of its stakeholders" (Malik, Nawab, Naeem \& Danish, 2010"13). The literature proposes that people become devoted to institutes for different of reasons, such as an affective attachment to norms and values of the institute, a recognition of the costs incurred in leaving the institute, and a sense of responsibility to the institute (Suma \& Lesha, 2013). Comprehending how workers derive satisfaction and commitment towards their institutions, and to what extent different elements add towards being committed, is really imperative to improve their performance. However, it is worth noting that in education organizational commitment has been studied. For instance, Balay (2006:12) focused on "administrators and teachers in private and public secondary schools"; Hart and Willower, (1994:1) investigated "principals' organizational commitment and school environmental robustness"; Günbaş and Demir (2017:1) determined "the effect of principal behaviours on teacher commitment"; Botha and Coetzee (2012:11) examined "the languishment of employee commitment in the light of perceptions of fair treatment in the workplace"; Mafini and Dlodlo (2014:1) investigated "the linkage between work-related factors, employee satisfaction and organisational commitment: Insights from public health professionals" as well as Coetzee, Mitonga-Monga and Swart (2014:23) who determined "human resource practices as predictors of engineering staff's organisational commitment".

Along these lines, finding from a collection of writings and to the best information of the researchers, few investigations have tended to and analyzed work spirituality and procedural justice as antecedents of work locus control which ultimately result in work satisfaction and commitment to the institution. Thus, the present investigation is aimed at determining the the influence of workplace spirituality and procedural justice on work locus of control, work satisfaction and commitment to the institution among private higher education institutions in South Africa.

\section{REVIEW OF LITERATURE}

\subsection{Workplace spirituality (WS)}

Chinomona (2017:693) is of the view that "workplace spirituality or spirituality in the workplace is about the recognition that meaningful work and sense of community are essential for the spiritual growth of employees". "Spirituality in the workplace is about individuals and organizations seeing work as a spiritual path, as an opportunity to grow and to contribute to society in a meaningful" (Chinomona, 2017:693). In addition, Hassan, Bin-Nadeem and Akhter (2016:1) points out that "workplace spirituality inculcates past practices of interconnectivity and a feeling of trust between individuals, who are a part of a particular work process, which subsequently instigate cooperative feelings and lead to an overall organizational culture that is driven by motivation, exemplified by a positive response, and unanimity and harmony among the individuals, consequently, uplifting the cumulative performance of the individuals, and in turn aiding to the organizational excellence as a whole". Van der Walt and de Klerk (2014:12) "define workplace spirituality as the recognition of an inner life that nourishes and is nourished by meaningful work that takes place in the context of community".

\subsection{Procedural Justice (PJ)}


Procedural justice is defined as "participants' perceptions about the fairness of the rules and procedures that regulate a process" (Al-Zu'bi 2010:103). Furthermore, Cropanzana, Bowen and Gilliland (2007:12) "points out that procedural justice refers to the means by which outcomes are allocated, but not specifically to the outcomes themselves". Tyler (2011:1) "views procedural justice as the study of people's subjective evaluations of the justice of procedures - whether they are fair or unfair, ethical or unethical, and otherwise accord with people's standards of fair processes for social interaction and decision-making". According to Baldwin (2006:2) "procedural justice is concerned with decision process leading to a popular outcome". However, van Prooijen (2009) notes that to what degree do employees feel that they are treated equitably by managers during hearings. Furthermore, Muzumdar, (2012:35) posit that "procedural justice constitutes the organizational frame in which employees obtain information about the changes which affects them, making possible to understand, accept, and/or negotiate new rules". Moreover, the study adopts the definition of procedural justice from Matteson (2002:43) who defined procedural justice as "the extent to which fair procedures and processes are in place and adhered to and to which individuals see their leaders as being fair and sincere and logical or rational in what they do".

\subsection{Work Locus of Control (WLC)}

Shannak and Al-Taher (2012:375) defines locus of control as "the extent to which individuals believe that they can control events that affect them". Furthermore, Ahluwalia and Preet (2016:75) noted that "work locus of control is defined as a generalized belief about control over events in the workplace". Precisely, it relates to rewards or outcomes within the organisational context such as promotions, bonuses, salary increases and job perks (Ntsebeza, 2011). It is argued by Thomas, Eby and Sorensen (2006:1059) that "work locus of control is the extent to which employees believe that they have control over their own destiny in the workplace". In addition, Shaik and Buitendach (2015:375) "describe work locus of control in relation to a personality construct and work focus of control is described as a perception that one can personally affect particular outcomes". Additionally, Elena, Chavez, Carlos, Rojas, Arturo-Cordova and Moreno (2015) are of the view that locus of control is the perception that a person has control that may be exercised with respect to the work place. Moreover, Shaik and Buitendach (2015) points out that it is related to numerous key work-related outcomes such as psychological capital, happiness, work satisfaction, organisational citizenship behaviour, turnover intentions and job performance.

\subsection{Job satisfaction (JS)}

As indicated by Al-Zu'bi (2010) employee job satisfaction includes particular parts of fulfillment identified with remuneration, advancement, service conditions, management, hierarchical practices and associations with collaborators. Employee job satisfaction (EJS) is the emotions and musings of representatives about their work and work environment (Rizwan, Khan, Tariq, Ghaffar, Anjum, and Bajwa, 2012). Likewise, Javed, Balouch and Hassan (2014) agreed that work satisfaction has been interconnected with how individuals think, feel and watch their occupations. Rahman, Akhter and Khan (2017) suggested that job satisfaction among the employees can be accomplished by enabling and allowing individuals enough commitment to build up their psychological level objectively; work happiness is a lovely or empowering expressive state inside work aptitudes. Moreover, Davis and Newstrom (1989) characterized job satisfaction is an arrangement of positive or troublesome emotions with which representatives see their work.

\subsection{Organisational commitment (OC)}

Khan, Rashidm and Vytialingam (2016:1) defined organisation commitment as "employee's emotional attachment to identification with and involvement in a particular organisation, specifically addressing affective commitment, which is one of the organisation's commitments". Sigh, Gupta, and Venugopal (2008:59) defined “employee organizational commitment as a concept embracing an employee's desire 
to remain in an organization, willingness to exert effort on its behalf, and belief in and acceptance of the values and goals of the organization". In addition, Chinomona \& Moloi (2014) describe organisation commitment as that commitment people believe in and accept the goals and values of the organisation. Workers are eager to continue with their institutes and are keen to expend considerable effort on their behalf (Cater \& Zabka, 2009). In this way, a committed worker is portrayed as the individual who continues with an institution through various challenges, goes to work frequently, puts in an entire day's worth of effort, and secures organization's advantages, shares organization's objectives, and so forth.

\section{Research Model}

Figure 1, displays the six hypothesised associations in this paper.

Figure 1: The conceptual model

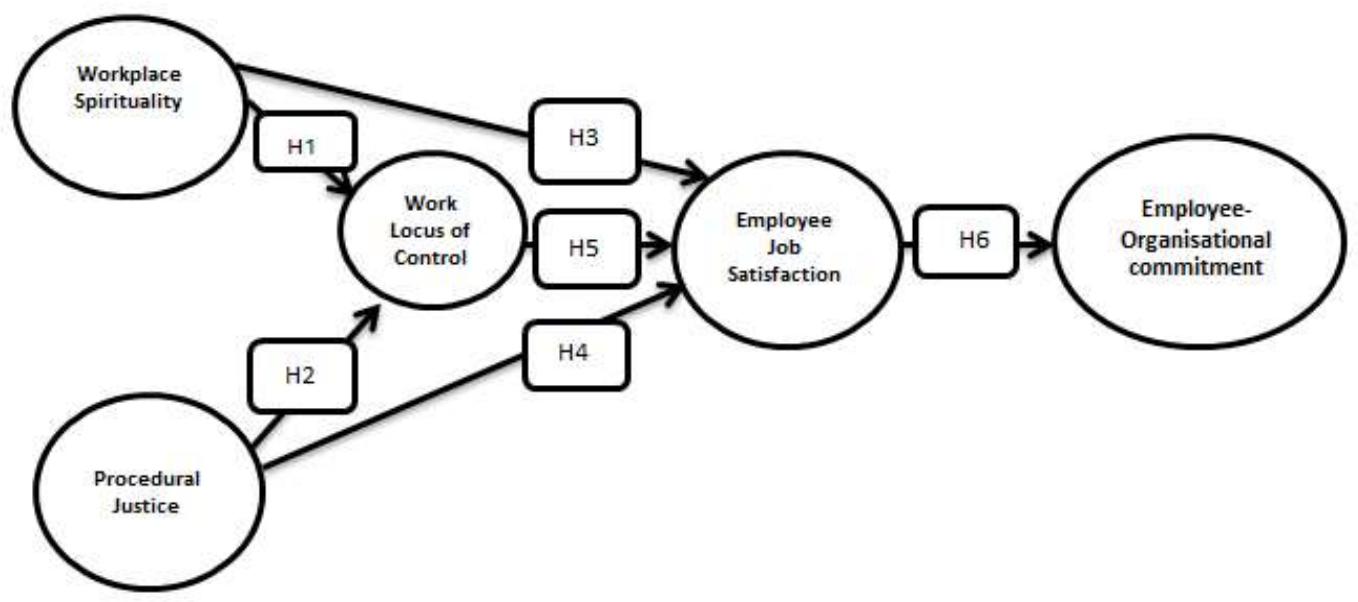

\subsection{Workplace spirituality and work locus of control}

According to Janfeshan, Panahy, Veiseh, Seid-Mehdi and Kamari (2011:12) "enterprises that base on spirituality can attain success, self-actualization development and workers' happiness, stimulating trustworthiness, respect, duty and integrity". People with a great spirit at work have a positive influence on individual well-being (Kinjerski \& Skrypnek, 2006). Companies with higher regards to employees' reward systems usually achieve higher organizational performance (Rotter, 1966). Additionally, Johnson, Batey and Holdsworth (2009:13) suggest that "work spirituality and fulfilment of employees' rewards needs is positively associated". This is consistent with Arnold, Turner, Barling, Kelloway and McKee (2007) who discovered that there is a positive relationship between work spirituality and work locus of control. Therefore, it can be stated that:

\section{H1: There is has a positive relationship between workplace spirituality and work locus of control}

\subsection{Procedural justice and work locus of control}

Perceived procedural justice has been noted to influence survivor reactions in the post layoff environment and it has been noted that when procedural justice is low, survivor reactions - work attitudes as well as behaviours, are seen to be more negative (Abasimi, Atindanbila \& Kwakye-Nuak 2014). In addition, Lilly and Virick, (2006) found out that procedural justice has a significant positive relationship with work locus of control. These results are also in line with Sweeney, McFarlin and Cotton (1991) who found out that locus of control was related to procedural justice. Therefore, deducing from the aforementioned literature the authors are self-assured to postulate the following hypothesis: 


\section{H2: There is has a positive relationship between procedural justice and work locus of control}

\subsection{Workplace spirituality and job satisfaction}

Asrun (2012) discovered that spirituality in workplace has a positive significant effect on job satisfaction. Van der Walt and de Klerk (2014) found out that workplace spirituality is positively related to job satisfaction. Fairbrother and Warn (2003) discovered that workplace spirituality has a direct impact and influence on job satisfaction. Moreover, Chawla, and Guda (2010) established a positive relationship between workplace spirituality and job satisfaction. Thus, drawing from the above mentioned discussion, it is therefore hypothesized that:

H3: There is has a positive relationship between workplace spirituality and employee job satisfaction

\subsection{Procedural justice and job satisfaction}

Most of the studies have shown high correlations between procedural justice and job satisfaction (Awamleh \& Fernandes, 2006, Mossholder, Bennett, \& Martin, 1998; Wesolowski \& Mossholder, 1997:1). Al-Zu'bi (2010) proved that there was a positive association between procedural justice and job satisfaction. Futheremore, Rahman, Haque, Elahi, and Miah (2015:1) elucidated that "when employees are involved in the decision making process they cooperate". Moreover, Masterson, Lewis, Goldman and Taylor (2000) in their study found that procedural justice is an effective predictor of workers' degree of happiness. Therefore, inferring from the literature and the empirical evidence above, it is hypothesized that:

H4: There is has a positive relationship between procedural justice and employee job satisfaction

\subsection{Work locus of control and job satisfaction}

Chen and Silverthorne (2008) suggested that locus of control is a significant predictor of job satisfaction. Vijayashree and Jagdischchandra (2011) discovered that there is a positive correlation between internal locus of control and job satisfaction as well as between external (other) locus of control and job satisfaction. Omari and Kidombo (2013) points out that people who feel they are in control may be more satisfied than those who are not. Muhonen and Torkelson, (2004:1) their results depicted that work locus of control was a significant predictor of job satisfaction. Therefore, inferring from the literature and the empirical evidence above, it is hypothesized that:

\section{H5: There is has a positive relationship between work locus of control and employee job satisfaction}

\subsection{Job satisfaction and organisational commitment}

Ntisa (2015) posit that there is a causal link between job satisfaction and organisational commitment. In addition, Kotze and Roodt (2005) found a significant positive relationship between employee satisfaction and organisational commitment. Similarly, Azeem (2010) emphasised that if employees' levels of satisfaction increase, then levels of organisational commitment would be affected in a positive direction. Therefore, deducing from the aforementioned it can be hypothesised that:

H6: There is has a positive relationship between employee job satisfaction and employee organisational commitment

\section{Method}


The examination utilized a quantitative research configuration utilizing an organized survey. "In quantitative research, information are measured to apply factual systems with a specific end goal to increase significant bits of knowledge into connections" (Dhurup, Mafini and Dumasi 2014:1). Furthermore, the design was applicable to elicit the needed data relating to the variables under investigation.

\subsection{Sampling and participants}

Information was gathered from representatives working at private tertiary institutions of education in the Gauteng Province of South Africa. In particular, the objective populace was confined to scholastics and care staff in a private college setting in Gauteng, South Africa, predominantly centering in Johannesburg. Of the aggregate of 170 surveys appropriated, 150 usable polls were recovered for the last information examination, speaking to a reaction rate of $89 \%$. Participants were request to give a background about their socio economic data. The example comprised of females ( $n=87 ; 58 \%)$. The middle age gathering of the respondents was that of under 30 years $(n=82 ; 54.6 \%)$. A large portion of the respondents showed that they are hitched speaking to $(n=90 ; 60 \%)$ of the aggregate example and the rest of; (40\%) demonstrated that they are single. Half of the members had under 5 years working background $(\mathrm{n}=71 ; 47.3 \%)$, in excess of a fourth of the members had 5-10 years working knowledge $(n=59 ; 39.3 \%)$, and not as much as a quarter had over 10 years working knowledge $(n=18 ; 12.1 \%)$.

\subsection{Measurement instrument and questionnaire design}

According to Malhotra (2010:225) “a questionnaire was chosen as a measuring instrument, as it is simple to administer and reduces the variability in the results that may be caused by differences in other types of interviews". In addition, research scales were adapted from previous related works. WS was adapted from Kolodinsky, Giacalone, and Jurkiewicz (2008), (PJ) was adapted from Blader, and Tyler (2003); WLC was adapted from Spector (1988). JS was adapted was from Ntisa (2015) and (OC) was adapted from Mowday, Steers and Porter (1979).

\section{Table 1: Demographic data}

\begin{tabular}{|l|l|l|}
\hline Gender & Frequency & Percentage \\
\hline Male & 63 & $42 \%$ \\
\hline Female & 87 & $58 \%$ \\
\hline Total & $\mathbf{1 5 0}$ & $\mathbf{1 0 0 \%}$ \\
\hline Age & Frequency & Percentage \\
\hline$\leqq 30$ & 82 & $54.6 \%$ \\
\hline $31-60$ & 50 & $33.3 \%$ \\
\hline$\geqq 60$ & 18 & $\mathbf{1 2 . 1 \%}$ \\
\hline Total & $\mathbf{1 5 0}$ & $\mathbf{1 0 0 \%}$ \\
\hline Marital status & Frequency & Percentage \\
\hline Married & 90 & $60 \%$ \\
\hline Single & 60 & $40 \%$ \\
\hline Total & $\mathbf{1 5 0}$ & $\mathbf{1 0 0 \%}$ \\
\hline Participants working experience & Frequency & Percentage \\
\hline$\leqq 5$ years & 73 & $48.6 \%$ \\
\hline $5-10$ years & 59 & $39.3 \%$ \\
\hline$\geqq 10$ years & 18 & $12.1 \%$ \\
\hline Total & $\mathbf{1 5 0}$ & $\mathbf{1 0 0 \%}$ \\
\hline
\end{tabular}

\section{Data analysis and results}


A Microsoft Excel spreadsheet was used to code the field data. The Statistical Packages for Social Sciences (SPSS) and the Smart PLS programming for Structural Equation Modeling (SEM) system were used to analyse the information. Since the present investigation sample size is generally small (150) Smart PLS was discovered more fitting and befitting the motivation behind the present examination.

\subsection{Reliability analysis}

The statistical measures of accuracy tests shown in Table 2, specify the different measures that were used to assess the reliability and validity of the constructs for the study. Unequivocally, the table portrays means and Standard deviations (SD), Item to Total relationships, Cronbach alpha esteems, Average change separated (AVE), Composite Reliability (CR) and Factor Loadings.

Table 2: Accuracy analysis statistics

\begin{tabular}{|c|c|c|c|c|c|c|c|c|}
\hline \multirow{2}{*}{\multicolumn{2}{|c|}{ Research constructs }} & \multicolumn{2}{|c|}{$\begin{array}{l}\begin{array}{l}\text { Descriptive } \\
\text { statistics* }\end{array} \\
\end{array}$} & \multicolumn{2}{|c|}{ Cronbach's test } & \multirow[b]{2}{*}{ C.R. } & \multirow[b]{2}{*}{ AVE } & \multirow[b]{2}{*}{$\begin{array}{l}\text { Measurement } \\
\text { Item Loadings }\end{array}$} \\
\hline & & Mean & SD & Item-total & $\begin{array}{l}\text { Cronbach } \\
\text { Alpha } \\
\text { Value }\end{array}$ & & & \\
\hline \multirow{16}{*}{$\begin{array}{l}\text { Work-place spirituality } \\
\text { (WPS) }\end{array}$} & WPS4 & \multirow{16}{*}{3.88} & \multirow{16}{*}{1.188} & 0.800 & \multirow{16}{*}{0.933} & \multirow{16}{*}{0.942} & \multirow{16}{*}{0.507} & 0.547 \\
\hline & WPS5 & & & 0.810 & & & & 0.590 \\
\hline & WPS6 & & & 0.811 & & & & 0.545 \\
\hline & WPS7 & & & 0.824 & & & & 0.667 \\
\hline & WPS8 & & & 0.733 & & & & 0.760 \\
\hline & WPS9 & & & 0.746 & & & & 0.689 \\
\hline & WPS10 & & & 0.607 & & & & 0.796 \\
\hline & WPS11 & & & 0.800 & & & & 0.808 \\
\hline & WPS12 & & & 0.780 & & & & 0.828 \\
\hline & WPS13 & & & 0.771 & & & & 0.830 \\
\hline & WPS14 & & & 0.751 & & & & 0.740 \\
\hline & WPS15 & & & 0.793 & & & & 0.712 \\
\hline & WPS16 & & & 0.728 & & & & 0.763 \\
\hline & WPS17 & & & 0.730 & & & & 0.722 \\
\hline & WPS18 & & & 0.709 & & & & 0.625 \\
\hline & WPS19 & & & 0.773 & & & & 0.682 \\
\hline \multirow{8}{*}{ Procedural Justice (PJ) } & PJ1 & \multirow{8}{*}{3.78} & \multirow{8}{*}{1.668} & 0.659 & \multirow{8}{*}{0.909} & \multirow{8}{*}{0.926} & \multirow{8}{*}{0.612} & 0.837 \\
\hline & PJ2 & & & 0.782 & & & & 0.819 \\
\hline & PJ3 & & & 0.852 & & & & 0.780 \\
\hline & PJ4 & & & 0.816 & & & & 0.814 \\
\hline & PJ5 & & & 0.876 & & & & 0.742 \\
\hline & PJ6 & & & 0.780 & & & & 0.775 \\
\hline & PJ7 & & & 0.871 & & & & 0.682 \\
\hline & PJ8 & & & 0.651 & & & & 0798 \\
\hline \multirow{13}{*}{$\begin{array}{l}\text { Work locus of control } \\
\text { (WLC) }\end{array}$} & WLC4 & \multirow{13}{*}{3.89} & & 0.726 & & & & 0.573 \\
\hline & WLC5 & & & 0.724 & & & & 0.617 \\
\hline & WLC6 & & & 0.779 & & & & 0.564 \\
\hline & WLC7 & & & 0.731 & & & & 0.674 \\
\hline & WLC8 & & & 0.707 & & & & 0.747 \\
\hline & WLC9 & & & 0.743 & & & & 0.669 \\
\hline & WLC10 & & 1.133 & 0.782 & 0.920 & 0.930 & 0.515 & 0.822 \\
\hline & WLC11 & & & 0.780 & & & & 0.826 \\
\hline & WLC12 & & & 0.771 & & & & 0.866 \\
\hline & WLC13 & & & 0.751 & & & & 0.796 \\
\hline & WLC14 & & & 0.793 & & & & 0.708 \\
\hline & WLC15 & & & 0.728 & & & & 0.672 \\
\hline & WLC16 & & & 0.730 & & & & 0.719 \\
\hline & EJS 1 & & & 0.713 & & & & 0.774 \\
\hline & EJS 2 & & & 0.743 & & & & 0.687 \\
\hline $\begin{array}{l}\text { Employee job satistaction } \\
\text { (EJS) }\end{array}$ & EJS 3 & 3.03 & 1.300 & 0.793 & 0.833 & 0.883 & 0.602 & 0.822 \\
\hline 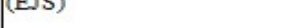 & EJS4 & & & 0.748 & & & & 0.804 \\
\hline & EJS 5 & & & 0.638 & & & & 0.785 \\
\hline & EOC1 & & & 0.780 & & & & 0.756 \\
\hline & $\mathrm{EOC} 2$ & & & 0.771 & & & & 0.780 \\
\hline $\begin{array}{l}\text { Employee organisational } \\
\text { commitment (EOC) }\end{array}$ & EOC3 & 3.10 & 1.655 & 0.751 & 0.854 & 0.891 & 0.578 & 0.780 \\
\hline Commiment (EUC) & $\mathrm{EOC4}$ & & & 0.793 & 0.854 & 0.891 & 0.218 & 0.734 \\
\hline & EOC5 & & & 0.728 & & & & 0.752 \\
\hline & EOC6 & & & 0.730 & & & & 0.757 \\
\hline
\end{tabular}

Note: $\mathrm{SD}=$ Standard Deviation, $\mathrm{CR}=$ Composite Reliability, AVE= Average Variance Extracted; 
Table 2 demonstrates that the item-total correlation values lies in the vicinity of 0.607 and 0.824 which is over the cut-off purpose of 0.5 as prescribed by Anderson and Gerbing (1988:411). The higher interitem correlations reveal convergence among the measured items. Futheremore, the Cronbach's coefficient alpha was utilized to survey the interior consistency of each develop utilized in the investigation. "The nearer the co-fficient is to 1.00, the more prominent is the inward consistency of the things in the scale" (Malhotra 2010:724). Every alpha value extended from 0.833 to 0.933 , they surpassed the prescribed limit of 7.0 recommending that every one of the things in the scale take advantage of the same basic develops (Hair et al., 2010:44) and this additionally demonstrates the constructs are exceptionally reliable and are clarifying increasingly that half of the difference. The results of composite reliability are appearing in Table 2. The outcomes yielded CR indexes in the vicinity of .883 and .930. The exhibited CR level exceeded the estimated criteria of greater than 0.70 , which is recommended as adequate for internal consistency of the constructs (Nunnally 1978:247; Chin 1988:320), thus finding support for the scales satisfactory composite reliability. Moreover, convergent validity of the study was determined by computing AVE values. AVE is the average of communalities for each latent factor in a reflective model. According to Malhotra (2010) the AVE values should be at least 0.50, which means that the construct explains at least half of the variance of its observed variables. Chin (1998) also points out that AVE values below 0.50 indicate error variance levels that surpass the explained variance. Thus, the AVE values reported in this study were within the acceptable range $(0.507 \leq \mathrm{AVE} \leq 0.602)$, implying that more of the variance along each indicator variable was shared with its respective construct.

Table 3: Inter - Construct Correlation Matrix

\begin{tabular}{|l|l|l|l|l|l|}
\hline $\begin{array}{l}\text { Research } \\
\text { Construct }\end{array}$ & $\begin{array}{l}\text { Work-place } \\
\text { spirituality } \\
\text { Justice }\end{array}$ & $\begin{array}{l}\text { Procedural } \\
\text { control }\end{array}$ & $\begin{array}{l}\text { Work locus of } \\
\text { job } \\
\text { satisfaction }\end{array}$ & $\begin{array}{l}\text { Employee } \\
\text { organisational } \\
\text { commitment }\end{array}$ \\
\hline $\begin{array}{l}\text { Work-place } \\
\text { spirituality }\end{array}$ & 1.000 & & & & \\
\hline $\begin{array}{l}\text { Procedural } \\
\text { Justice }\end{array}$ & $.460^{* *}$ & 1.000 & & & \\
\hline $\begin{array}{l}\text { Work locus of } \\
\text { control }\end{array}$ & $.353^{* *}$ & $.374^{* *}$ & 1.000 & 1.000 & \\
\hline $\begin{array}{l}\text { Employee job } \\
\text { satisfaction }\end{array}$ & $.414^{* *}$ & $.422^{* * *}$ & $.419^{* *}$ & $.588^{* *}$ & 1.000 \\
\hline $\begin{array}{l}\text { Employee } \\
\text { organisational } \\
\text { commitment }\end{array}$ & $.374^{* * *}$ & $.513^{* * *}$ & $.439^{* *}$ & & \\
\hline
\end{tabular}

\subsection{Inter-Construct Correlation Matrix}

Nunnally and Bernstein (1994) demonstrates that one of the strategies used to check for discriminant validity of the research variables was the assessment of whether the relationships among latent variables were under 0.60 . A correlation value of under 0.60 is prescribed in the empirical literature to affirm the presence of discriminant validity (Nunnally and Bernstein 1994). As can be seen every one of the relationships are underneath the standard level of 0.60 which show the presence of discriminant validity As appeared in Table 1, the inter-construct correlation esteems extended from 0.353 to 0.588 underneath the dependable guideline of 0.8 (Fraering and Minor, 2006), showing the fulfillment of discriminant validity. In this way, table 3, above demonstrates that the outcomes additionally approve the presence of discriminant legitimacy.

\subsection{Assessment of the goodness of fit (GoF)}


Overall, $\mathrm{R}^{2}$ for workplace spirituality, procedural justice, work locus of control, employee job satisfaction and employee organisational commitment in Figure 2, show that the exploration demonstrate clarifies $60.1 \%$ and $44.5 \%$ individually of the fluctuation in the endogenous factors. The following formulae given by Tenenhaus, Vinzi, Chatelin and Lauro, (2005), the global goodness-of-fit (GoF) statistic for the research model was calculated using the equation:

Goodness of Fit $=2 \sqrt{(\text { average of all AVEs values* average of all R2) }}$

$=2 \sqrt{0.563^{*} 0.539}$

$=0.55$

Where AVE speak to the normal of all AVE esteems for the exploration factors while $\mathrm{R}^{2}$ speaks to the normal of all $\mathrm{R}^{2}$ esteems in the full way demonstrate. alculated global goodness of fit (GoF) is 0.55 , which surpass the limit of GoF > 0.36 recommended by Wetzels, Odekerken-Schröder and van Oppen (2009). Subsequently, this investigation presumes that the examination demonstrates has a decent general fit.

\subsection{Path Model Results and Factor Loadings}

The PLS estimation results for the structural model and the item loadings for the research constructs are shown in Figure 2.

\section{Figure 2: Path Modelling and Factor Loading Results}

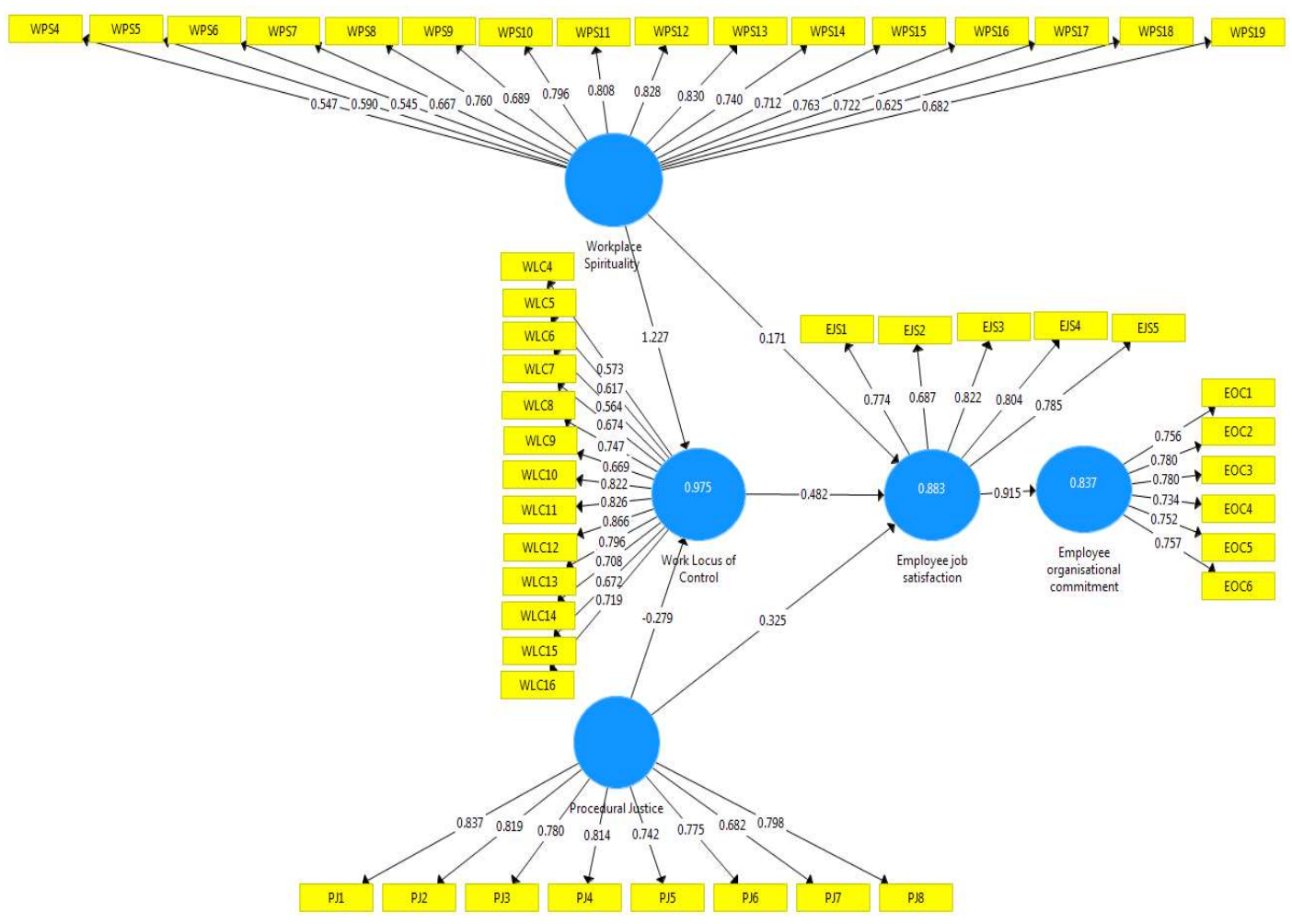

Table 4: Results of structural equation model analysis 


\begin{tabular}{|c|c|c|c|c|}
\hline Path & Hypothesis & $\begin{array}{l}\text { Path coefficients } \\
(\beta)\end{array}$ & $\begin{array}{l}\text { T- } \\
\text { Statistics }\end{array}$ & Decision \\
\hline $\begin{array}{l}\text { Workplace spirituality } \rightarrow \\
\text { Work locus of control }\end{array}$ & $\mathrm{H} 1(+)$ & 1.227 & 25.291 & $\begin{array}{l}\text { Positive } \\
\text { and } \\
\text { significant }\end{array}$ \\
\hline $\begin{array}{l}\text { Procedural Justice } \rightarrow \text { Work } \\
\text { locus of control }\end{array}$ & $\mathrm{H} 2(+)$ & -0.279 & 1.691 & $\begin{array}{l}\text { Negative } \\
\text { but } \\
\text { insignificant }\end{array}$ \\
\hline $\begin{array}{l}\text { Work-place } \text { spirituality } \\
\text { Employee job satisfaction }\end{array}$ & $\mathrm{H} 3(+)$ & 0.171 & 2.510 & $\begin{array}{l}\text { Positive } \\
\text { and } \\
\text { significant }\end{array}$ \\
\hline $\begin{array}{l}\text { Procedural Justice } \\
\text { Employee job satisfaction }\end{array}$ & $\mathrm{H} 4(+)$ & 0.482 & 0.476 & $\begin{array}{l}\text { Positive } \\
\text { and } \\
\text { insignificant }\end{array}$ \\
\hline $\begin{array}{l}\text { Work locus of control } \rightarrow \\
\text { Employee job satisfaction }\end{array}$ & $\mathrm{H} 5(+)$ & 0.325 & 2.510 & $\begin{array}{l}\text { Positive } \\
\text { and } \\
\text { significant }\end{array}$ \\
\hline $\begin{array}{ll}\text { Employee job } & \text { satisfaction } \rightarrow \\
\text { Employee } & \text { organisational } \\
\text { commitment } & \end{array}$ & H6(+) & 0.915 & 55.424 & $\begin{array}{l}\text { Positive } \\
\text { and } \\
\text { significant }\end{array}$ \\
\hline
\end{tabular}

\section{Outcome of Hypotheses Testing}

In this study testing of the hypothesis will be determined by the path coefficient values as well as the tvalues for the structural model obtained from the bootstrapping algorithm. According to Beneke and Blampied (2012) T-values indicate whether or not a significant relationship exists between variables within the model and path coefficients demonstrate the strength of the relationships in the model. Two tailed $t$-tests were conducted at the five percent significance level.

6.1 Outcome of Hypotheses Testing Hypothesis 1: There is has a positive relationship between workplace spirituality and work locus of control

The PLS model showed that there is a significant positive relationship at the five percent level of significance $(t-v a l u e=25.291)$ between workplace spirituality and work locus of control as hypothesised. This effect has a Beta value of 1.227, which means that there is a positive relationship between workplace spirituality and work locus of control. H1 is accepted at the five percent level of significance and conclude that workplace spirituality has a significant positive on work locus of control.

6.1 Outcome of Hypotheses Testing 2: There is has a positive relationship between procedural justice and work locus of control

Hypothesis 2 posited a positive relationship between procedural justice and work locus of control. However, the result in Table 4 and Figure 2, indicates that they is a negative $(\beta=-0.279)$ but insignificant $(t=1.691)$ relation between procedural justice and work locus of control. Therefore, $H 2$ is rejected since the relationship between procedural justice and work locus of control was negative and insignificant.

6.2 Outcome of Hypotheses Testing 3: There is has a positive relationship between workplace spirituality and employee job satisfaction

Hypothesis 3 posited a positive association between workplace spirituality and employee job satisfaction. Consistent with Hypothesis 1, results indicated that higher levels of work place spirituality will lead to higher levels of employee job satisfaction $(\beta=0.171 ; t=2.510)$. Therefore, H3 is accepted 
since the relationship between work place spirituality and employee job satisfaction was positive and significant.

6.4 Outcome of Hypotheses Testing 4: There is has a positive relationship between procedural justice and employee job satisfaction

In this study, this hypothesis was supported. It can be observed in Figure 2 and Table 4 that procedural justice exerted a positive influence $(\beta=0.482)$ and was statistically insignificant $(t=0.476)$ in predicting employee job satisfaction. This result suggests that procedural justice positively influence employee job satisfaction however the significant level is weak.

6.5 Outcome of Hypotheses Testing 5: There is has a positive relationship between work locus of control and employee job satisfaction

Figure 2 and Table 4 above, indicate that H5, is supported by the hypothesis finding $(\beta=0.325)$ and is significant at $t$-statistics 2.510. Again, the strength of the association is indicated by a path coefficient of 0.325 . This implies that work locus of control is positively related to employee job satisfaction in a significant way.

6.6 Outcome of Hypotheses Testing 6: There is has a positive relationship between employee job satisfaction and employee organisational commitment

It is depicted in Figure 2 and Table 4 that H6 is supported significantly. The t-statistics is 55.424 . The strength of the relationship is indicated by the path coefficient of 0.915 . This finding suggests that employee job satisfaction has a direct strong positive effect on employee organizational commitment. So the more employees are satisfied with their jobs, the more the more they are committed to their jobs.

\section{Scholastic, reasonable and strategy suggestions for the investigation}

The present examination offers suggestions for academicians. For instance, an examination of the exploration discoveries show Work-place spirituality Work locus of control has the most grounded impact on each other as demonstrated by the path coefficient of (1.227) when contrasted with other research variables. Consequently, for academicians in the field of human capital administration this discovering improves their comprehension of the connection between -place spirituality and work locus of control as this is a helpful commitment to existing writing on these two variables.

On the experts' side, this investigation in this way presents principals or grounds supervisors inside private organizations of higher learning can benefit by the ramifications of these discoveries. For instance, given the strong connection between representative job satisfaction and employee organizational commitment (0.915), principals or grounds supervisors inside private foundations of higher learning they should focus or they should put more accentuation on discovering ways that makes their representatives fulfilled to their employments and this will at last make them to be focused on their employments. In addition, the present examination offers suggestions for approach creators who have been creating arrangements that make representatives to be fulfilled and focused on their employments. Unequivocally; arrangements which exist in different foundations of higher learning can be altered to introduce representative occupation fulfillment and worker hierarchical responsibility. In this way, the outcomes which have been acquired from this examination might be utilized to create new arrangements and modification of the current approaches.

\section{Restrictions and future research proposals}


This investigation has a few constraints which ought to be featured. Initially, the utilization of a moderately sample size, one cannot self-assuredly sum up the discoveries, despite the fact that various demographic questions were utilized as a part of a push to decide how illustrative the sample was of the characterized target populace. In future research, a more extensive populace including a few advanced education institutions ought to be considered. Unequivocally additionally contemplating of state-claimed organizations of higher learning would be likewise valuable for further study. Every one of the information in the examination were gathered quantitatively, which prompted the regular technique inclination inborn to quantitative strategies. Future investigations can attempt to center around triangulation techniques to maintain a strategic distance from this biasness. Future research researchers could center around different variables that impact workers to be fulfilled and in addition to be focused on their occupations. For example, these variables can contain motivation strategies such as training and rewards for employees. Besides, relative examinations between the aftereffects of this investigation and those acquired from other non-instructive foundations or through meta-examinations could likewise be considered later on. This could prompt other provocative experiences that were not caught in the present examination.

\section{Conclusion}

This examination was led with the expectation to research the impact of workplace spirituality and procedural justice on work locus of control, employee job satisfaction and employee organisational commitment among employees from private institutions of high learning in South Africa. The investigation approves that elements, for example, workplace spirituality, procedural justice and work locus of control are instrumental in invigorating employee job satisfaction and employee job commitment. Workplace spirituality was found to strongly affect work locus of control when compared to procedural justice. A strong association was likewise found on the nexus between employee job satisfaction and employee organizational commitment. The outcomes bolster all the hypothesized statement with the exception of hypothesis four which, although positive as postulated, was insignificant as well as the hypothesis two which exposed negative and insignificant results. Administrative ramifications of the discoveries were discussed about and confinements and future research headings were shown. Well beyond, this will study immensely contribute new knowledge to the existing body of organisational behaviour and human resources management literature in the African setting - an examination setting which happens to be unnoticed by researchers.

\section{References}

Abasimi, E., Atindanbila, S. \& Kwakye-Nuak, C.O. 2014. Perception of procedural justice on organizational commitment of survivors' of layoffs in selected organizations in Ghana. The international journal of social sciences, 22(1), 31-47.

Ahluwalia, A., \& Preet, M. K. 2016. Locus of Control among University teachers: an Empirical Study. International Journal of Engineering Technology Science and Research, 3(1), 75-80.

Al-Zu'bi, H. A. 2010. A study of relationship between organizational justice and job satisfaction. International Journal of Business and Management, 5(12), 102-109.

Anderson, J. C., \& Gerbing, D. W. 1988. Structural Equation Modeling in Practice: A Review and Recommended Two-Step Approach. Psychological Bulletin, 103(3), 411-423.

Arnold, K.A., Turner, N., Barling, J., Kelloway, E. K., \& McKee, M.C. 2007. Transformational leadership and psychological well-being: the mediating role of meaningful work. Journal of occupational health psychology, 12(3), 193-199. 
Azeem, S.M. 2010. Job satisfaction and organizational commitment among employees in the Sultanate of Oman. Psychology, 1, (4), 295-299.

Balay, R. 2006. Conflict management strategies of administrators and teachers. Asian Journal of Management Cases, 3(1), 5-24.

Beneke, J \& Blampied, S. 2012. Driving Consumer Perceptions through Facebook: An Investigation into Empowering Brands in the 21st Century. The Southern Africa Institute for Management Scientists (SAIMS). Conference Proceedings of the 24th Annual Conference of SAIMS - 2012. 9 -11 September 2012.

Botha, J. A., \& Coetzee, M. 2012. The languishment of employee commitment in the light of perceptions of fair treatment in the workplace. South African Journal of Human Resource Management, 10(2), 1-11.

Cater, B. \& Zabkar, V. 2009. “Antecedents and Consequences of Commitment in Marketing Research Services: The Client's Perspective," Industrial Marketing Management, 38(7), 785-797.

Chawla, V., \& Guda, S. 2010. Individual spirituality at work and its relationship with job satisfaction, propensity to leave and job commitment: An exploratory study among sales professionals. Journal of Human Values, 16, 157-167.

Chen, J. C., \& Silverthorne, C. 2008. The impact of locus of control on job stress, job performance and job satisfaction in Taiwan. Leadership \& Organization Development Journal, 29(7), 572-582.

Cherian, J., \& Jacob, J. 2013. Impact of self-efficacy on motivation and performance of employees. International Journal of Business and Management, 8(14), 80-91.

Chinomona, E. 2017. Modelling The Influence Of Workplace Spirituality, Quality Of Work Life, Expectations Towards Work On Commitment To Long-Term Career Of Employees In Gauteng Province, South Africa. Journal of Applied Business Research (JABR), 33(4), 691-702.

Chinomona, E., \& Moloi, K. C. 2014. The Role Played by Institutional Support in the Commitment, Job Satisfaction and Employee Performance of Teachers in Gauteng Province of South Africa: A Social Exchange Perspective. Mediterranean Journal of Social Sciences, 5(2), 303-315.

Coetzee, M., Mitonga-Monga, J., \& Swart, B. 2014. Human resource practices as predictors of engineering staff's organisational commitment. SA Journal of Human Resource Management, 12(1), 1-9.

Cropanzana, R., Bowen, D.E. and Gilliland, S.W., 2007. The management of organizational justice. The Academy of Management Perspectives, 34-48.

Cropanzano, R., Bowen, D.E., \& Gilliland, S.W. 2007. The management of Organizational Justice. Academy of Management perspectives (November), 34-48.

Davis, K and Newstrom, J.W. 1989. Human Behavior at Work Organizational Behavior, New York; McGraw-Hill.

Dajani, M.A.Z. 2015. The impact of employee engagement on job performance and organisational commitment in the Egyptian banking sector. Journal of Business and Management Sciences, 3(5), 138-147.

Elena, M., Chavez, E., Carlos, K., Rojas, R., Arturo Cordova, G., \& Elena Moreno, S. 2015. Empirical evidence on locus of control among owner and manager and its relation to success firms. Journal of Emerging Trends in Economics and Management Sciences (JETEMS), 6(3), 177-184 
Fairbrother, K.,\& Warn, J.2003. Workplace dimensions, stress and job satisfaction. Journal of Managerial Psychology, 18, 8-21.

Fernandes, C., \& Awamleh, R. 2006. Impact of organisational justice in an expatriate work environment. Management research news, 29(11), 701-712.

Fitzgerald, C. S., \& Clark, S. 2013. Work Locus of Control and Perceptions of Practice. Journal of Public Child Welfare, 7(1), 59-78.

Giacalone, R.A. , \& Jurkiewicz , C.L . 2003. Right from wrong: The infl uence of spirituality on perceptions of unethical business activities. Journal of Business Ethics, 46, 85 - 97

Günbaş, N., \& Demir, Ö. 2017. Are We Measuring Teachers' Attitudes towards Computers in Detail?: Adaptation of a Questionnaire into Turkish Culture. International Journal of Assessment Tools in Education (IJATE), 4(2), 13-34.

Hassan, M., Bin Nadeem, A., \& Akhter, A. 2016. Impact of workplace spirituality on job satisfaction: Mediating effect of trust. Cogent Business $\mathcal{E}$ Management, 3(1), 1-15.

Heisserer, D.L., \& Parette, P. 2002. Advising at-risk students in college and university settings. College student journal, 36(1). 1-14.

Janfeshan, K., Panahy, B., Veiseh, Seid-Mehdi, Kamari, F. 2011. Spirituality in The Workplace and Its Impacts on the Efficiency of Management. 2nd International Conference on Business and Economic Reseach (2nd Icber 2011) Proceeding.

Javed, M., Balouch, R., \& Hassan, F. 2014. Determinants of Job Satisfaction and its impact on Employee performance and turnover intentions. International journal of learning and development, 4(2), 120-140.

Johnson, S.J., Batey, M., \& Holdsworth, L. 2009. Personality and health: The mediating role of trait emotional intelligence and work locus of control. Personality and Individual Differences, 47(5), 470-475.

Khan, S. K., Rashid, M.Z.H.A., \& Vytialingam, L.K. 2016. The Role of Organisation Commitment in Enhancing Organisation Citizenship Behaviour: A Study of Academics in Malaysian Private Universities. International Journal of Economics E Management, 10(2) 221-239.

Kinjerski, V., \& Skrypnek, B.J. 2006. Creating organizational conditions that foster employee spirit at work. Leadership E Organization Development Journal, 27(4), 280-295.

Kotze, K., \& Roodt, G. 2005. Factors that affect the retention of managerial and specialist staff: an exploratory study of an employee commitment model. South African Journal of Human Resource Management, 3(2), 48-55.

Lilly, J.D., \& Virick, M. 2006. The effect of personality on perceptions of justice. Journal of Managerial Psychology, 21(5), 438-458.

Mafini, C., \& Dlodlo, N. 2014. The linkage between work-related factors, employee satisfaction and organisational commitment: Insights from public health professionals. SA Journal of Human Resource Management, 12(1), 1-12.

Maiese, M. 2004. "Procedural Justice." Beyond Intractability. Eds. Guy Burgess and Heidi Burgess. Conflict Information Consortium, University of Colorado, Boulder. Posted: January 2004

<http://www.beyondintractability.org/essay/procedural-justice>. 
Malik, M.E., Nawab, S., Naeem, B., \& Danish, R.Q. 2010. Job satisfaction and organizational commitment of university teachers in public sector of Pakistan. International Journal of Business and Management, 5(6), 1-7.

Masterson, S.S., Lewis, K., Goldman, B.M., \& Taylor, M. S. 2000. Integrating justice and social exchange: The differing effects of fair procedures and treatment on work relationships. Academy of Management Journal, 43: 738-748.

Mossholder, K.W., Bennett, N., \& Martin, C.L. 1998. A multilevel analysis of procedural justice context. Journal of Organizational Behavior, 19, 131-141

Mowday, R.T., Steers, R. M., \& Porter, L. W. 1979. The measurement of organizational commitment. Journal of vocational behavior, 14(2), 224-247.

Muhonen, T., \& Torkelson, E. (2004). Work locus of control and its relationship to health and job satisfaction from a gender perspective. Stress and Health, 20(1), 21-28.

Mullins, L. J. 2007. Management and organisational behaviour. Pearson education. New York.

Muzumdar, P., 2012. Influence of interactional justice on the turnover behavioral decision in an organization. Journal of Behavioral Studies in Business, 5, 31-41.

Ntisa, A.A. 2015. Job satisfaction, organisational commitment, turnover intention, absenteeism and work performance amongst academics within South African Universities of Technology. Doctoral dissertation, Vaal University of Technology. Vanderbijlpark. South Africa.

Ntsebeza, C. 2011. The role of leader-member-exchange in mediating the relationship between work locus of control and job satisfaction, Master's Degree in Industrial Psychology, University of the Witwatersrand, Johannesburg.

Omari, S.M., \& Kidombo, H. 2013. Human resource practices, the relationship between locus of control and employee outcomes. DBA Africa Management Review, 3(1), 90-99.

Pohlman, R., \& Gardiner, G. 2000. Value driven management: How to create and maximize value over time for organizational success. Amacom Div American Mgmt Assn.

Rahman, K.U., Akhter, W., \& Khan, S.U. 2017. Factors affecting employee jobsatisfaction: A comparative study of conventional and Islamic insurance. Cogent Business $\mathcal{E}$ Management, 4(1), 1-15.

Rahman, M., Haque, M., Elahi, F., \& Miah, W. (2015). Impact of organizational justice on employee job satisfaction: an empirical investigation. American Journal of Business and Management, 4(4), 162-171.

Rizwan, M., Khan, W.M., Tariq, H. M. A., Ghaffar, A., Anjum, M. Z., \& Bajwa, E. U. 2012. Empirical study of Employee job Satisfaction. IOSR Journal of Business and management, 29-35.

Rotter, J.B. 1966. Generalized expectancies for internal versus external control of reinforcement. Psychological monographs: General and applied, 80(1), 1-13.

Shaik, Z., \& Buitendach, J.H. 2015. The relationship between work locus of control and psychological capital amongst middle managers in the recruitment industry of South Africa. South African Journal of Human Resource Management, 13(1), 1-12.

Shannak, R.O \& Al-Taher, A. 2012. Factors affecting Work Locus of Control: An Analytical and Comparative Study. Jordan Journal of Business Administration, 8(2), 373-389. 
Singh B., Gupta P., \& Venugopal S. (2008). Organizational commitment: Revisited. Journal of the Indian Academy of Applied Psychology, 34 (1), 57-68.

Suma, S., \& Lesha, J. 2013. Job satisfaction and organizational commitment: The case of Shkodra municipality. European Scientific Journal, 9(17), 23-35.

Sweeney, P.D., McFarlin, D.B., \& Cotton, J.L. 1991. Locus of control as a moderator of the relationship between perceived influence and procedural justice. Human Relations, 44(4), 333-342.

Thomas, W., Eby, L., \& Sorensen, K. 2006. Locus of control at work: a meta-analysis. Journal of Organizational Behaviour, 27, 1057-1087.

Van der Walt, F., \& de Klerk, J.J. 2014. Workplace spirituality and job satisfaction. International Review of Psychiatry, 26(3), 379-389.

Vijayashree, L., \& Jagdischchandra, M.V. 2011. Locus of control and job satisfaction: PSU employees. Serbian Journal of Management, 6(2), 193-203.

Wesolowski, M.A., \& Mossholder, K.W. 1997. Relational demography in supervisor subordinate dyads: Impact on subordinate job satisfaction, burnout, and perceived procedural justice. Journal of Organizational Behaviour, 18, 351-362. 